\title{
Specific fatty acids as metabolic modulators in the dairy cow
}

\author{
J.A.A. Pires and R.R. Grummer
}

Department of Dairy Science, University of Wisconsin, Madison, USA

ABSTRACT - This review summarizes recent developments on the utilization of specific fatty acids to modulate bovine energy metabolism, with emphasis on the periparturient dairy cow. A number of experiments have assessed the effects of polyunsaturated fatty acids on bovine hepatic energy metabolism using in vitro and in vivo models. Treatment of hepatocytes with specific fatty acids altered energy metabolism in vitro. For example, linolenic acid seemed to decrease hepatocyte triacylglycerol accumulation. This effect was confirmed in vivo, using parenteral infusions of emulsions derived from different fat sources to feed-restricted non-lactating cows. Additionally, polyunsaturated fatty acids can increase whole body response to insulin, potentially enhancing antilipolytic effects of insulin and muscle protein anabolism in the bovine. There is limited literature on the effects of feeding fat sources rich in omega-3 polyunsaturated fatty acids, such as fish oil and linseed oil, on metabolism of periparturient dairy cows. Available research has yielded conflicting results which need further clarification. On the other hand, specific isomers of conjugated linoleic acid consistently induce milk fat depression and are able to decrease energy export in milk by periparturient dairy cows. Nonetheless, research is still needed to assess whether these effects will ultimately benefit productivity and health status of periparturient dairy cows. Limitations of available methods to protect fatty acids from ruminal biohydrogenation are also addressed.

Key words: bovine, CLA, linseed, fish oil, metabolism, polyunsaturated fatty acid

\section{Introduction}

Lactation performance of dairy cows depends to a large extent on their ability to cope with metabolic demands of the periparturient period. The incidence of metabolic disorders and infectious disease peaks during this time of the production cycle (Drackley, 1999; Goff \& Horst, 1997; Grummer, 1993; Grummer, 1995), causing the culling rate to be greater in early lactation. A survey conducted in Minnesota between 1996 and 2001 has shown that $25 \%$ of all cows leaving farms did so during the first 60 days in milk (Godden et al., 2003).

The periparturient period is characterized by changes in estrogen and progesterone, growth hormone, insulin, glucocorticoids, and catecholamines, and by modifications in the response of target tissues to these hormones (Bauman, 2000; Bell \& Bauman, 1997; Chilliard et al., 2000). Plasma nonesterified fatty acid (NEFA) concentration gradually increases during the last two weeks of gestation and peak at calving (Grummer, 1993; Vazquez-Añon et al., 1994). Additionally, there is a gradual decline in dry matter intake (DMI), especially during the last week of gestation. The depression of DMI leads to negative energy balance at calving (Doepel et al., 2002; Hayirli et al., 2003; Rabelo et al., 2003), promoting further mobilization of body reserves. Fat depots and labile protein reserves are mobilized, leading to reduction of the diameter of skeletal muscle fibers and loss of body condition (Roberts et al., 1981). Negative energy balance continues through the first weeks of lactation, due to the steady increase in milk production and to the slower rate of increase in feed intake (Grummer, 1993; Roberts et al., 1981).

Liver takes up fatty acids (FA) proportionally to NEFA concentration in blood and blood flow (Emery et al., 1992). The liver may receive up to $38 \%$ of cardiac output, therefore it is susceptible to an oversupply of NEFA when arterial concentrations are elevated (Reynolds et al., 2003). In liver, NEFA can be fully oxidized, partially oxidized to ketones and secreted into blood, or re-esterified to triacylglycerol (TG). Since the ruminant liver has a limited ability to secrete TG as constituent of very low density lipoproteins, intensive mobilization of fat reserves leads to hepatic TG accumulation (Drackley, 1999; Grummer, 1993; 
Grummer, 1995; Roberts et al., 1981). Experimentally induced ketosis is preceded by accumulation of TG and depletion of glycogen in liver (Veenhuizen et al., 1991). In vitro studies have shown that TG accumulation in hepatocytes impairs gluconeogenesis (CadornigaValino et al., 1997) and depresses ureagenesis (Strang et al., 1998). This reduction in the ability to detoxify ammonia may occur in vivo, at a time when amino acids become important precursors for gluconeogenesis. For instance, the requirements for glucogenic amino acids mobilized from muscle and other labile reserves have been estimated to be about $500 \mathrm{~g} / \mathrm{d}$ on $\mathrm{d} 4$ of lactation. Probably as a result of the interactions previously described, high levels of circulating NEFA have been associated with decreased DMI and a number of metabolic disorders such as fatty liver, ketosis, displaced abomasum, reproductive failure and infectious disease (Drackley, 1999; Goff \& Horst, 1997; Grummer, 1993; Grummer, 1995).

Research from a variety of animal models has shown that polyunsaturated fatty acids (PUFA) can alter many aspects of metabolism and physiology, namely by promoting gene expression of key enzymes involved in lipid oxidation and decreasing expression of lipogenic enzymes (Sampath \& Ntambi, 2004). This review will focus on recent developments on the utilization of specific fatty acids to modulate bovine energy metabolism, with the ultimate goal of improving the metabolic status and productive performance of the periparturient dairy cow.

\section{Data from in vitro hepatocyte cultures}

A number of experiments have focused on the effects of PUFA on bovine hepatic energy metabolism. Mashek et al. (2002) assessed the metabolic fate of FA and their effects on palmitic acid (C16:0) metabolism in bovine hepatocytes using radiolabeled FA. Hepatocytes were isolated from ruminating calves and were incubated in suspension for 3 hours. Culture media included 1mM C16:0 plus 1mM of either oleic (C18:1), linoleic (C18:2n-6), alpha-linolenic (C18:3n-3), eicosapentaenoic (C20:5n-3), or docosahexaenoic acid (C22:6n-3). In general, PUFA were poor substrates for TG synthesis, and decreased C16:0 acid incorporation into hepatocyte TG and total lipids. Rates of oxidation to $\mathrm{CO}_{2}$ were greater for $\mathrm{C} 22: 6 \mathrm{n}-3$ and intermediate for
C20:5n-3 (these FA are abundant in fish oil), and the addition of $\mathrm{C} 20: 5 n-3$ induced the highest rates of $\mathrm{C} 16: 0$ oxidation to $\mathrm{CO}_{2}$ followed by $\mathrm{C} 18: 1$ and $\mathrm{C} 22: 6 \mathrm{n}-3$.

A follow-up experiment studied the long-term (48 hours) effects of FA on metabolism of hepatocytes collected from pre-ruminant calves and cultured in monolayer (Mashek \& Grummer, 2003). Treatments included $1 \mathrm{mM} \mathrm{C16:0}$ plus $1 \mathrm{mM}$ of other FA. Treatments containing C22:6n-3 increased total TG content in cells and enhanced the incorporation of C16:0 into cellular TG, which contrasted with results from previous experiments (Mashek et al., 2002). Overall, treatment with C18:3n-3 (plus C16:0) led to the lowest numerical value of TG accumulation of all PUFA studied (Mashek \& Grummer, 2003).

A third experiment was conducted to investigate the effects of different FA on lipid metabolism and gene expression (quantification of mRNA) of apolipoprotein B100 (ApoB100), apolipoprotein E (ApoE), and microsomal triglyceride transfer protein (MTP). These proteins are involved in synthesis and secretion of very low density lipoprotein by hepatocytes, which is the route of TG export from liver. Hepatocytes were isolated from pre-ruminating Holstein calves, cultured in monolayer, and treated for 48 hours with either no FA added (control) or $0.1,0.2$ and $1.0 \mathrm{mM}$ of single FA (C16:0, C18:0, C18:1, C18:2n-6, C18:3n-3, C20:5n-3 or C22:6n-3), or a physiological FA mix ("NEFA mix"; 15\% C18:0, 30\% C16:0, 45\% C18:1, 5\% C16:1, and $5 \% \mathrm{C} 18: 2 \mathrm{n}-6)$. In general, increasing the length and degree of unsaturation of FA decreased TG accumulation and down-regulated gene expression of ApoB, ApoE and MTP. Incubation with $\mathrm{C} 20: 5 \mathrm{n}-3$ or C22:6n-3 did not result in TG accumulation, probably because long chain PUFA are poor substrates for TG synthesis when present as the sole FA source (Mashek et al., 2002). However, adding C20:5n-3 or C22:6n-3 increased $\beta$-hydroxybutyrate production relative to control, which shows that these FA were being absorbed and oxidized by hepatocytes. Concentration effects of the "NEFA mix" and single FA treatments differed. Increasing the concentration of single FA enhanced TG accumulation and down-regulated gene expression of ApoE and MTP. Increasing the concentration of "NEFA mix", which reflects the FA profile in vivo, enhanced TG accumulation, but also upregulated gene expression of ApoB100, ApoE and MTP (Pires et al., 2006; Pires et al., 2004). 


\section{Effects of intravenous administration of different fat sources on energy metabolism}

In order to clarify discrepancies observed in in vitro studies, an experiment was performed to assess the effects of different FA sources on hepatic and whole body energy metabolism in vivo (Mashek et al., 2005). Six non-lactating Holstein cows were feed-restricted during 4 days to induce fatty liver, and were infused intravenously with emulsions derived from three TG sources with distinct FA composition: tallow (contains the same FA profile of ruminant fat depots), linseed oil ( $>50 \% \mathrm{C} 18: 3 \mathrm{n}-3$ ) and fish oil (a source rich in C20:5n-3 and $\mathrm{C} 22: 6 \mathrm{n}-3)$ in a replicated $3 \times 3$ Latin square design. Cows receiving emulsions derived from linseed oil had the lowest plasma NEFA and $\beta$-hydroxybutyrate concentrations. Liver TG accumulation was lower for linseed oil than fish oil, tended to be lower for linseed oil than tallow, and did not differ between tallow and fish oil. Hepatic FA oxidation was not affected by treatments, which indicates that differences in TG accumulation may have been mediated by extra-hepatic effects of FA (Mashek et al., 2005). Authors speculated that modifications in adipose tissue metabolism by C18:3n-3 originating from linseed oil may have increased capillary lipoprotein lipase activity and uptake of circulating NEFA by peripheral tissues. Additionally, C18:3n-3 may have enhanced sensitivity of adipose tissue insulinmediated inhibition of lipolysis, therefore, decreasing plasma NEFA concentrations and FA uptake by the liver (Mashek et al., 2005).

\section{Modulation of insulin action by polyunsaturated fatty acids}

Insulin resistance develops during the periparturient period and increases the availability of glucose, amino acids and FA to mammary gland (Bell, 1995; Bell \& Bauman, 1997). Conceptually, exaggerated insulin resistance may enhance the degree of FA mobilization from adipose tissue, and further increase plasma NEFA concentration (Pires et al., 2007a; Pires et al., 2007b), which is associated with onset of energy-related metabolic disorders (Grummer, 1993). Induction of hyperlipidemia by intravenous infusion of tallow emulsion caused insulin resistance in
Holstein cows, which was probably due to increased supply of NEFA derived from TG hydrolysis (Pires et al., 2007b). Accordingly, decreasing plasma NEFA concentration using nicotinic acid as an antilipolytic agent enhanced the response to insulin in feed-restricted cows, thus implicating plasma NEFA as a causal factor of insulin resistance in the bovine (Pires et al., 2007a).

Dietary FA profile can modulate the response to insulin in non-ruminants; particularly, omega-3 PUFA, such as $\mathrm{C} 18: 3 \mathrm{n}-3, \mathrm{C} 20: 5 \mathrm{n}-3$ and $\mathrm{C} 22: 6 \mathrm{n}-3$, may prevent development of insulin resistance in humans and rodents (Clarke, 2000; Delarue et al., 2004; Storlien et al., 2000). Several mechanisms have been proposed: modifications of membrane fluidity and changes in insulin receptor number or receptor affinity to insulin (Storlien et al., 1991; Storlien et al., 1987), alterations in blood lipids, amount and distribution of body fat (Delarue et al., 2004; Vessby, 2000), reduction of intracellular TG (Storlien et al., 1991), enhancement of intracellular insulin signaling (Gingras et al., 2007; Taouis et al., 2002), increased GLUT4 gene expression and GLUT4 translocation to muscle membranes (Taouis et al., 2002), and alteration of gene expression due to binding of PUFA to transcription factors, such as PPAR $\alpha$ and PPAR $\gamma$, which change gene expression and energy metabolism, reducing lipogenesis and increasing lipid oxidation (Clarke, 2000).

In agreement with findings from non-ruminants, abomasal infusion of fish oil (4\% of DMI) to beef steers increased key intermediaries of intracellular insulin signaling cascade in muscle, enhanced whole body insulin-induced disposal of amino acids and glucose, decreased amino acid oxidation and promoted protein anabolism, compared to a control fat source composed of $60 \%$ cotton oil and $40 \%$ olive oil (Gingras et al., 2007). Although assessment of feed efficiency was not in the scope of this study due to very limited animal numbers, feed efficiency may have been improved because feed intake to BW gain ratio was numerically lower for fish oil than control (5.4 vs. $6.57 \mathrm{~kg}$ DMI $/ \mathrm{kg}$ BW gain). The same research group has found similar positive effects on protein anabolism when neonatal pigs were fed a milk formula containing fish oil (Bergeron et al., 2007). Future research should address potential beneficial effects of marine oil supplementation on muscle accretion of growing ruminants (Gingras et al., 2007). 
There is limited information on the effects of C18:3n-3 on insulin resistance. Two studies showed enhanced whole body response to insulin when rodents were fed fat sources rich in C18:3n-3 (Mustad et al., 2006; Storlien et al., 1991). We hypothesized that changing the FA profile in blood serum of Holstein cows, by enriching its content with C18:3n-3, would enhance whole body response to insulin, potentially increasing insulin antilipolytic effects during periods of negative energy balance (Pires et al., 2008). One experiment was conducted to study the effects of abomasal infusion of linseed oil, a source rich in C18:3n-3, on whole-body response to insulin. Eight nonlactating, nongestating cows were assigned to a crossover design, fed at a rate to meet maintenance requirements and infused abomasally with either linseed oil (LIN) or tallow (TAL) at a rate of $0.54 \mathrm{~g} / \mathrm{kg} \mathrm{BW}$ per day for 5.5 days. Intravenous glucose tolerance (IVGTT) tests were performed on day 5 of each period, followed by insulin challenges (IC) 12 hours later. Clearance of glucose during IVGTT and IC was not affected by treatments, but insulin concentration during IVGTT was lower when cows received linseed oil, which suggests that linseed oil had an insulin sensitizing effect.

A second experiment assessed the effects of linseed oil infusion on insulin antilipolytic action during negative energy balance. Six nonlactating, nongestating cows were assigned to a replicated $3 \times 3$ Latin square design. The experimental protocol was similar to the one previously described, except that it included a water treatment, and feeding was suspended on day 3 , leading to 50 and 62 hours of feed restriction before IVGTT and IC, respectively. Feed-restriction was employed to induce a lipolytic state and increase plasma NEFA concentration. Glucose and insulin concentrations did not differ across treatments during IVGTT or IC, which contrasted with the previous experiment. Plasma NEFA concentration immediately prior IVGTT tended to be greater for LIN than for TAL (612 vs. $508 \mu \mathrm{Eq} / \mathrm{L}$ ). Plasma NEFA clearance rate during IVGTT was significantly greater for LIN than for TAL, leading to a shorter time to reach half NEFA concentration and greater NEFA response area under the curve during IVGTT. There were no differences in glucose and NEFA clearance during IC. Data from IVGTT suggest that LIN enhanced the antilipolytic effects of insulin.
However, these results should be interpreted with caution because, unexpectedly, plasma NEFA concentration before IVGTT and IC was approximately $100 \mu \mathrm{Eq} / \mathrm{L}$ greater for LIN than TAL, and other factors could have been involved.

Studies involving hyperinsulinemic euglycemic clamps in sheep have shown that the sensitivity of adipose tissue to the antilipolytic effects of insulin is greater than whole body sensitivity to insulin-dependent glucose utilization (Petterson et al., 1993; Petterson et al., 1994). This means as insulin concentration in blood increases, it will first inhibit lipolysis, and greater concentrations will be required to induce hypoglycemia. Therefore, it is possible that increasing whole body sensitivity to insulin during the periparturient period (for instance by using dietary supplementation of PUFA), would decrease lipolytic rates and reduce plasma NEFA concentrations, while maintaining muscle refractory to insulin-mediated glucose uptake. The effects of supplementation with $\mathrm{C} 18: 3 \mathrm{n}-3$ on responses to insulin need to be further investigated in periparturient cows.

\section{Polyunsaturated fatty acids and energy metabolism of periparturient cows}

The bulk of research involving supplementation of fat sources rich in omega-3 PUFA, such as fish oil and linseed oil, to dairy diets has focused on interactions with reproductive physiology (Ambrose et al., 2006; Mattos et al., 2003; Mattos et al., 2004; Moussavi et al., 2007b; Staples et al., 1998). Few studies have assessed the effects of these fat sources on energy metabolism of periparturient dairy cows; moreover, available literature reports conflicting results.

Mattos et al.(2004) supplemented primiparous and multiparous cows with $200 \mathrm{~g} / \mathrm{d}$ of either olive oil $(61 \% \mathrm{C} 18: 1$ and $20 \%$ saturated FA) or fish oil $(36 \%$ C20:5n-3 and 28\% C22:6n-3) from $21 \mathrm{~d}$ prior to expected calving until 21 days in milk. Animals that suffered distocia, metabolic disorders and infectious diseases were excluded from the dataset. Final number of primiparous and multiparous cows was 1 and 7 for olive oil, and 2 and 4 for fish oil treatment, respectively. Milk production did not differ between treatments, but cows receiving fish oil had lower milk fat percentage and lower plasma glucose than animals receiving olive 
oil. Cows were pen-fed, therefore, individual DMI and energy balance was not measured.

Moussavi et al. (2007) fed multiparous cows isonitrogenous, isoenergetic and isolipidic diets containing $2.3 \% \mathrm{DM}$ of calcium salts of palm oil (control; $\mathrm{n}=6)$, calcium salts derived from fish oil $(\mathrm{n}=$ 7 ), or 3 grading amounts of fish meal (not discussed in this review), from 5 to 50 days postpartum. Intake of C20:5n-3 and C22:6n-3 was 22.8 and $13.4 \mathrm{~g} / \mathrm{d}$ for cows receiving fish oil, but the proportion of these FA escaping rumen biohydrogenation is unknown. Feed intake, milk production, blood glucose and insulin were greater for cows receiving fish oil than control, which suggests improved metabolic status. Milk fat content did not differ. Neither of these two studies assessed diet effects on liver metabolites (Mattos et al., 2004; Moussavi et al., 2007a).

Canadian researchers have studied the effects of supplementing linseed, also referred to as flaxseed, to dairy rations. However, most studies used cows during established lactation. Petit et al (2007) fed Holstein heifers $(n=15)$ and multiparous $(n=18)$ cows one of three isonitrogenous and isoenergetic diets: control or diets supplemented with whole linseed (LINS; 56.8\% of total FA was C18:3n-3), or a mostly saturated fat source (SAT; containing 87.8\% saturated FA and $10.3 \%$ monounsaturated FA) from 6 weeks prior to expected calving until 28 days post-partum. Diet fat contents were $2.7,4.2$ or $4.1 \%$ of DM during prepartum, and $4.6,6.8$ or $7.3 \%$ of DM during postpartum, for control, LINS and SAT, respectively. Feeding SAT decreased pre- and post-partum DMI, depressed milk production and impacted metabolic profile of both primiparous and multiparous cows. Negative metabolic effects of SAT were particularly intense in multiparous cows, which experienced sustained negative energy balance, abnormally high plasma NEFA and $\beta$-hydroxybutyrate concentrations, and the greatest liver TG and lowest liver glycogen concentrations. Differences in diet composition and poor acceptability may have reduced SAT intake. Because source of FA was confounded by energy intake, a clear relationship between dietary FA profile (SAT vs. LINS) and energy metabolism in periparturient cows cannot be established from this study. Milk production, plasma glucose, NEFA, or $\beta$ hydroxybutyrate concentrations did not differ between control and LINS. Primiparous cows fed LINS had greater liver glycogen concentration on week 2 postpartum, and multiparous had lower liver TG concentration on week 4 and greater liver glycogen concentration on weeks 2 and 4 post-partum compared to control. Differences between control and LINS cannot be attributed specifically to diet FA profile because diet fat content was not the same across these two treatments. Although results suggest that LINS improved hepatic energy metabolism compared to control, limited number of animals per treatment within each parity group, and differences in diet fat content preclude making definitive conclusions.

The same research group tested the effects of feeding Megalac (calcium salts of FA; 47\% C18:0 and 32\% C18:1), LINS, or micronized soybeans (SOY; 57\% C18:2n-6, 21\% C18:1 and 7\% C18:3n-3) to Holstein cows $(\mathrm{n}=90)$ during the first 16 weeks of lactation (Petit, 2002). Dry matter intake and BW did not differ across treatments. Cows fed LINS or SOY had greater milk yield than cows receiving Megalac (35.7, 34.4, and $33.5 \mathrm{~kg} / \mathrm{d}$, respectively), and lower milk fat percentage (3.8, 3.7, and 4.1\%, respectively), with no differences between LINS and SOY. Milk protein percent was greater for LINS than for the other two fat sources. These results support a positive effect of feeding unsaturated fat sources on productive performance of early lactation cows.

Under the premise that changing diet fat content or diet FA profile prepartum would have a carry-over effect during early lactation, Andersen et al. (2008) assigned 28 Holstein dry cows to one of three isonitrogenous and isoenergetic diets: control, control supplemented with LINS (60\% of total FA was C18:3n3 ), or SAT (90.5\% of total FA were saturated, 5.7\% was C18:1). Diet fat content was $2.1,7.9$ and $8.1 \%$ of DM for control, LINS and SAT, respectively. Treatments started 5 weeks before expected calving and daily feed allotment was restricted during the pre-partum period to meet estimated nutrient requirements. All cows were allowed ad libitum intake of the same lactation diet and data was collected until week 6 post-partum. Cows fed SAT during the dry period had the lowest plasma NEFA concentration at week 0 and 1 post-partum, and the lowest liver TG concentration at week 2 post-partum. Cows fed LINS had the lowest glucose concentration on week 0 and 3 post-partum. Authors concluded that 
feeding LINS during dry period was not beneficial, and that supplementation with a saturated fat source would improve energy metabolism postpartum. Yet, treatments did not affect post-partum DMI, change in body weight and body condition score, milk yield or milk components.

The experiments previously described involved different assumptions and methodological approaches to assess effects of PUFA on dairy cattle energy metabolism. Results point to opposite conclusions: fish oil does not change milk yield and decreases plasma glucose (Mattos et al., 2004), or fish oil increases DMI, milk yield and plasma glucose (Moussavi et al., 2007a); supplementation with linseed during puerperium may be beneficial (Petit, 2002; Petit et al., 2007), or supplementation with saturated fat prepartum improves energy metabolism compared to linseed (Andersen et al., 2008). How can one reconcile these results? It should be kept in mind that periparturient dairy cows are highly variable in their ability to cope with the onset of lactation, metabolic profile is influenced by factors not directly dependent on diet composition (e.g., environmental and social interactions) and there is a complex relationship between nutrition and onset of various metabolic disorders and diseases. Under-replication is a frequent problem in nutrition trials during periparturient period because these experiments are labor intensive, time consuming, and expensive. Methods for handling data from cows with metabolic disorders or disease may differ among studies and are often not adequately described. Observations are frequently excluded from analysis due to onset of disorders, supposedly unrelated to dietary treatments. Conversely, data may be included under the supposition that milk production or blood metabolites were not affected. Invariably milk production or blood and liver metabolite data are analyzed statistically under the assumption that there is sufficient replication (i.e., statistical power). In contrast, data on health disorders typically are not analyzed statistically because they have binomial distribution (outcome is yes or no), requiring much more replication. However, given the large effect of health status on milk production (Edwards \& Tozer, 2004), can we say that a study has sufficient replication for detecting treatment effects on milk production and blood and liver metabolites, when there is insufficient replication to detect treatment effects on animal health? These limitations may ultimately lead to conflicting results among studies, and extrapolation of findings to a production setting should be done cautiously.

\section{Effect of specific fatty acids on milk fat depression}

Milk fat depression (MFD) in dairy cows is associated with feeding diets high in concentrate to forage ratio, PUFA, lush pastures and/or ionophores (Bauman \& Griinari, 2003; Griinari et al., 1998). It has been suggested that incomplete ruminal hydrogenation of dietary PUFA may lead to production of specific FA, that depress milk fat synthesis in mammary gland (Pennington \& Davis, 1975). This explanation for MFD is currently referred to as the biohydrogenation theory (Bauman \& Griinari, 2003). Griinari et al. (1998) fed diets differing in concentrate to forage ratio (80:20 vs. 50:50) which were supplemented with either a mostly saturated or unsaturated fat source. Diet fiber content and type of fat significantly affected milk fat percent and yield. Furthermore, feeding a low fiber diet plus unsaturated fat induced the greatest degree of MFD, demonstrating that severe MFD depends on the presence of both dietary unsaturated FA and altered rumen environment, which leads to incomplete ruminal biohydrogenation of dietary fat.

Trans isomers of $\mathrm{C} 18: 1$ have been implicated in MFD because their content in milk fat increases during diet-induced MFD (Bauman \& Griinari, 2003; Griinari et al., 1998) and abomasal infusion of hydrogenated vegetable oil containing mixed trans-C18:1 isomers causes MFD (Gaynor et al., 1994; Romo et al., 1996). Griinari et al. (1998) suggested that the degree of MFD may depend on specific trans C18:1 isomers rather than total amount of this class of FA, because trans-10 C18:1 in milk fat was a better indicator of diet-induced MFD than total trans-C18:1. Despite the association between milk fat content of trans-10 C18:1 and the degree of MFD across a wide variety of experimental conditions (Bauman \& Griinari, 2003; Shingfield \& Griinari, 2007), four-day abomasal infusion of trans-10 C18:1 at a rate of $42.6 \mathrm{~g} /$ day failed to induce MFD in late-lactation cows (Lock et al., 2007). Therefore, this study strongly argues against a cause-effect relation between trans-10 C18:1 and MFD, and implicates other isomers as causal of MFD. 
Conjugated linoleic acid (CLA) is a general term for a variety of positional and geometric isomers of linoleic acid with conjugated double bonds. Conjugated linoleic acid isomers occur in ruminant derived products, are produced in the rumen from incomplete biohydrogenation of dietary PUFA, and synthesized endogenously from trans-11 $\mathrm{C} 18: 1$ by delta-9 desaturase (Bauman et al., 2000; Griinari et al., 2000). The discovery of unique biological properties of CLA in experimental animal models, such as inhibition of carcinogenesis and atherosclerosis, immunomodulation, and reduction of fat accretion (Pariza, 2004; Pariza et al., 2001), led to intensive research on dietary manipulation of CLA content in beef and dairy products, namely by supplementation of PUFA that would serve as precursors for CLA synthesis (Chilliard et al., 2007).

Experiments aimed to assess the transfer of exogenous CLA isomers to milk fat showed that shortterm (one or five days) abomasal infusion of mixed CLA isomers induced MFD in mid-lactation cows (Chouinard et al., 1999a; Loor \& Herbein, 1998). A follow-up experiment was conducted to assess the effects of 4-day abomasal infusion of cis-9, trans-11 CLA (the most abundant CLA isomer in ruminant fat), or trans-10, cis-12 CLA (a putative precursor of trans$10 \mathrm{C} 18: 1$ in the rumen) on MFD. Infusion of $10 \mathrm{~g} /$ day of trans-10, cis-12 CLA decreased milk fat yield by $44 \%$, therefore implicating post-ruminal activity of this isomer in MFD (Baumgard et al., 2000).

Abomasal infusion of trans-10, cis-12 CLA (Baumgard et al., 2002b) and dietary induction of MFD (Peterson et al., 2003) to cows in positive energy balance decreased mammary tissue transcription of genes involved FA cellular uptake, transport, synthesis, desaturation and esterification. Abomasal infusion of trans-10, cis-12 CLA had the opposite effect in adipose tissue, up-regulating mRNA expression of lipogenic genes, which indicates partitioning of energy from milk fat towards adipose reserves (Harvatine et al., 2007). However, 20-week treatment of cows with a rumenprotected source of trans-10, cis-12 CLA decreased milk fat yield by $23 \%$, but did not alter DMI, milk yield, net energy balance or replenishment of body reserves (Perfield et al., 2002). The absence of CLA effects on energy balance and BCS could have been due to differential regulation of energy partitioning during short-term vs. long term CLA treatment, to differences in rates of CLA administration, or to the variability inherent to conventional feeding trials.

Researchers compared the degree of MFD from dose-response studies involving purified trans-10, cis12 CLA to the magnitude of effects from diet-induced MFD, and realized that MFD could not be fully explained by trans-10, cis-12 CLA alone (Bauman \& Griinari, 2003; Peterson et al., 2003). This observation led to research on a number of other CLA isomers, which has implicated cis-10, trans-12 CLA and trans-9, cis-11 CLA as causal of MFD (Perfield et al., 2007; Saebo et al., 2005). Nonetheless, increased milk fat content of these isomers does not mirror the extent of diet-induced MFD, and does not explain MFD caused by post-ruminal infusion of fat sources rich in transC18:1, suggesting that other unidentified rumen biohydrogenation intermediates (e.g., CLA and trans C18:1 isomers) are involved in MFD phenomenon (Kadegowda et al., 2008; Shingfield \& Griinari, 2007).

\section{Use of CLA in periparturient cows}

Dairy cows experience negative energy balance during the periparturient period, which is often associated with onset of metabolic disorders such as fatty liver and ketosis (Grummer, 1993). Researchers have been interested in using trans-10, cis-12 CLA to modulate energy metabolism of periparturient dairy cows, under the rational that decreasing fat output in milk would improve energy balance, and thus prevent metabolic disorders and enhance overall lactation performance (Bauman et al., 2008). A number of experiments have tested the effects of feeding rumen protected forms of CLA on metabolism and performance of dairy cows.

The effect of trans-10, cis-12 CLA on MFD and milk yield is dependent on the lactation phase. Treatment with CLA causes an almost immediate reduction in milk fat content in mid- and late-lactation cows, and, in most studies, no change in total milk production (Baumgard et al., 2000; Chouinard et al., 1999b; Loor \& Herbein, 1998; Perfield et al., 2002). However, the mammary gland seems to be refractory to CLA-induced MFD during the first weeks after calving (Bernal-Santos et al., 2003; Castaneda-Gutierrez et al., 
2005), and greater amounts of CLA are needed to elicit a gradual MFD during this period compared to mid- and late-lactation (Moore et al., 2004; Odens et al., 2007).

In contrast to results obtained during established lactation, milk production response to CLA supplementation has been inconsistent during early lactation, with either no change (Castaneda-Gutierrez et al., 2005), tendency to increase (Bernal-Santos et al., 2003) or significant increase in milk production (Odens et al., 2007). These discrepancies have been attributed to differences in energy balance (Castaneda-Gutierrez et al., 2005; de Veth et al., 2006; Odens et al., 2007), or to the amount of CLA given and magnitude of MFD (Odens et al., 2007). A positive milk yield response to CLA treatment may be more likely to occur during negative energy balance, due to repartition of energy (Castaneda-Gutierrez et al., 2005; de Veth et al., 2006). Odens et al. (2007) supplemented the diet of periparturient cows with calcium salts of CLA, providing trans-10, cis-12 CLA at an estimated rate of 0 or $9.8 \mathrm{~g}$ /day until 10 days in milk, and $0,2.8$ or 9.8 $\mathrm{g} /$ day thereafter. Supplementation with CLA induced MFD within the first week post-partum, but milk production did not differ across treatments until week 3 , which was after the nadir of negative energy balance (Odens et al., 2007). Perhaps the homeorhetic mechanisms orchestrating the establishment of lactation are challenged during first weeks post-partum, due to intensive negative energy balance characteristic of this period. Thus, CLA-induced inhibition of energy export as milk fat may be insufficient to elicit an immediate positive response in milk yield. As energy balance gradually improves during first weeks of lactation, cows may be able to repartition the energy spared by MFD and enhance milk yield.

One study involving supplementation with CLA to periparturient cows reported a significant decrease in plasma NEFA concentration and increase in plasma glucose during first weeks of lactation (Odens et al., 2007). Authors speculated that CLA treatment may have caused some degree of insulin resistance in peripheral tissues, therefore, decreasing glucose utilization. However, the response to insulin challenges was not affected by CLA treatment in mid-lactation cows fed ad libitum (Baumgard et al., 2002a), or feedrestricted to $80 \%$ of estimated ME requirements (de Veth et al., 2006). However, animals in the later study were not in a lipolytic state because plasma NEFA concentration was less than $160 \mathrm{uEq} / \mathrm{L}$, which is close to values observed in fed non-lactating cows (Pires et al., 2007a). It is conceivable that CLA effects on whole body glucose metabolism may be different depending on nutritional and metabolic status of the dairy cow.

Research is warranted to identify of other FA biohydrogenation intermediates that modulate energy metabolism in the ruminant, and assessment of potential synergistic effects between these FA. A better understanding of CLA effects on homeorhetic adaptations to lactation is also needed to explain different biological effects of CLA during early versus established lactation. Ultimately, field studies involving adequate number of animals and CLA supplementation will determine its effects on both productivity and metabolic health of periparturient dairy cows.

\section{Challenges on feeding specific fatty acids to ruminants}

Although forage derived lipids are rich in C18:2n-6 and C18:3n-3, and most grains are high in $\mathrm{C} 18: 1$ and $\mathrm{C} 18: 2 \mathrm{n}-6$, rumen microbial metabolism dramatically changes dietary FA via enzymatic isomerization and biohydrogenation. Extensive ruminal desaturation is thought to occur because PUFA are toxic to rumen microbes (Jenkins et al., 2008). As a result, FA profile reaching the duodenum is more saturated and includes unique FA not present in the diet, namely isomers of conjugated linoleic acid and trans isomers of oleic acid (Chilliard et al., 2007; Jenkins et al., 2008).

As previously reviewed, specific FA can modulate energy metabolism in the bovine. Strategies to enhance flow of PUFA to the duodenum include manipulation of ruminal biohydrogenation by changing diet components and inclusion of vegetable and/or marine oils (Chilliard et al., 2007), supplementation with raw or processed oilseeds rich in PUFA, and utilization of rumen-protected fats (e.g., calcium salts of FA and fatty acyl amides), which have less impact on rumen fermentation, and would theoretically enhance the proportion of unsaturated FA escaping ruminal biohydrogenation (Chilliard et al., 2007; Jenkins \& Bridges, 2007).

Jenkins \& Bridges (2007) summarized the extent of rumen FA biohydrogenation from 25 studies 
reporting intake and duodenal flow of specific FA. Ruminal FA loss was expressed as percent of total FA intake (diet plus fat supplement). Rumen disappearance of C18:2 and C18:3 from control diets, and diets supplemented with unprotected fats, oilseeds (whole and processed) and rumen-protected fats was 78.6, 78.9, 77.2 and $79.3 \%$, and $84.3,86.2,82.9$ and $85.8 \%$, respectively. Ruminal FA biohydrogenation was extensive and it was not affected by the form of dietary fat (free fat, oil seeds or rumen- protected). Nonetheless, duodenal flow of C18:2 and C18:3 was significantly greater when oilseeds were fed (Jenkins \& Bridges, 2007). Accordingly, milk C18:3n-3 content increases by 0.3 to $0.9 \mathrm{~g} / 100 \mathrm{~g}$ FA when dairy rations are supplemented with linseed (Chilliard et al., 2007), which indicates some supplemental C18:3n-3 reaches the intestine and is absorbed.

Extensive ruminal disappearance has also been reported for calcium salts of CLA. Ruminal transformation of CLA was assessed indirectly based on apparent transfer efficiency of trans-10, cis-12 CLA to milk fat. On average, $22 \%$ of trans-10, cis-12 CLA is exported to milk FA when the CLA source is infused abomasally, bypassing rumen metabolism (de Veth et al., 2005). Transfer efficiency is dramatically reduced when calcium soaps of CLA are fed, ranging between 1.7 and 7.4\% (de Veth et al., 2005; Odens et al., 2007). There is also a concomitant increase in milk trans C18:1 content, which suggests extensive ruminal biohydrogenation of calcium salts of CLA (Odens et al., 2007). Utilization of lipid-encapsulation as an alternative mean to protect trans-10, cis-12 CLA from rumen metabolism led to an apparent milk transfer efficiency of 2.4 to $7.4 \%$ (de Veth et al., 2006; Perfield et al., 2004). Nonetheless, even with limited protection from ruminal biohydrogenation, results show that it is possible to supply sufficient amounts of CLA isomers to induce MFD using rumen-protected forms of CLA that are presently available.

Incorporation of fish oil in dairy rations causes small and highly variable increases in milk C20:5n-3 and $\mathrm{C} 22: 6 \mathrm{n}-3$ content (less than $0.15 \%$ points); the transfer efficiency of dietary fish oil to milk FA is only 2.6\% for C20:5n-3 and 4.1\% for C22:6n-3 (Chilliard et al., 2001). This low efficiency is probably due to extensive ruminal biohydrogenation and preferential incorporation of long chain PUFA into blood serum phospholipids and cholesterol esters (Chilliard et al., 2001). Castaneda-Gutierrez et al. (2007) assessed the degree of rumen protection against biohydrogenation of C20:5n-3 and C22:6n-3 when calcium salts of fish oil were administered intra-ruminally, compared to ruminal and abomasal infusions of free fish oil. The transfer efficiency of C20:5n-3 and C22:6n-3 to milk FA was 21.3 and $18.9 \%$, respectively, when fish oil was infused into the abomasum. Transfer efficiency decreased to only 3.1 and $4.4 \%$ for C20:5n-3 and C22:6n-3, respectively, when calcium salts of fish oil was supplied. This means that approximately $87 \%$ of C20:5n-3 and 77\% of C22:6n-3 in calcium salts of fish oil was biohydrogenated in the rumen. Transfer efficiency of these FA was not different between calcium salts and free fish oil administered intraruminally, but ruminal infusion of unprotected fish oil caused MFD and decreased DMI. Therefore, utilization of calcium salts prevented negative effects on rumen digestion, but did not protect $\mathrm{C} 20: 5 \mathrm{n}-3$ and $\mathrm{C} 22: 6 \mathrm{n}-3$ against FA biohydrogenation.

It is not known whether the amount omega-3 FA escaping rumen biohydrogenation, and therefore potentially available for absorption, is sufficient to elicit metabolic effects observed in the bovine during i.v. (Mashek et al., 2005) and abomasal infusions (Pires et al., 2008), and whether limited flow of these FA to the duodenum might have impacted biological responses in studies involving periparturient cows (Andersen et al., 2008; Mattos et al., 2004; Moussavi et al., 2007a; Petit et al., 2007).

\section{Conclusions}

Research shows that PUFA can alter bovine metabolism and physiology, and dietary supplementation with these FA has the potential to improve the metabolic status and productive performance of the periparturient dairy cow. Nonetheless, in vitro and in vivo research assessing the utilization of omega-3 PUFA, such as C18:3n-3, C20:5n-3 and C22:6n-3, or fat sources rich in these FA, has yielded conflicting results which need further clarification. On the other hand, specific isomers of CLA consistently induce MFD, decreasing energy export in milk, but research is still needed to assess whether CLA-induced MFD may ultimately benefit 
metabolic health of the periparturient dairy cow. The absence of an efficient method to protect specific FA from ruminal biohydrogenation poses an important limitation for their strategic supplementation, and may partially explain divergent experimental outcomes when omega-3 FA sources were fed. Ultimately, determining the effects of supplementing specific FA on health and performance of early lactation cows will be dependent on trials employing larger animal numbers than have been traditionally used.

\section{References}

AMBROSE, D.J.; KASTELIC, J.P.; CORBETT, R., et al. Lower pregnancy losses in lactating dairy cows fed a diet enriched in $\{$ alpha\}-linolenic acid. Journal of Dairy Science, v.89, n.8, p.3066-3074, 2006.

ANDERSEN, J.B.; RIDDER, C.; LARSEN, T. Priming the cow for mobilization in the periparturient period: Effects of supplementing the dry cow with saturated fat or linseed. Journal of Dairy Science, v.91, n.3, p.1029-1043, 2008.

BAUMAN, D.E. 2000. Regulation of nutrient partitioning during lactation: Homeostasis and homeorhesis revisited. Pages 311-328 in Ruminant physiology: Digestion, metabolism, growth and reproduction. CRONJE, P.B., ed. CABI Publishing, Agricultural College, Edinburgh, UK.

BAUMAN, D.E.; BAUMGARD, L.H.; CORL, B.A., et al. Biosynthesis of conjugated linoleic acid in ruminants. Journal of Animal Science, v.77, n.E-Suppl, p.1-15, 2000.

BAUMAN, D.E.; GRIINARI, J.M. Nutritional regulation of milk fat synthesis. Annual Review of Nutrition, v.23, n.1, p.203227,2003

BAUMAN, D.E.; PERFIELD, J.W., II; HARVATINE, K.J., et al. Regulation of fat synthesis by conjugated linoleic acid: Lactation and the ruminant model. Journal of Nutrition, v.138, n.2, p.403-409, 2008.

BAUMGARD, L.H.; CORL, B.A.; DWYER, D.A., et al. Effects of conjugated linoleic acids (CLA) on tissue response to homeostatic signals and plasma variables associated with lipid metabolism in lactating dairy cows. Journal of Animal Science, v.80, n.5, p.1285-1293, 2002a.

BAUMGARD, L.H.; CORL, B.A.; DWYER, D.A., et al. Identification of the conjugated linoleic acid isomer that inhibits milk fat synthesis. American Journal of Physiology - Regulatory Integrative and Comparative Physiology, v.278, n.1, p.R179-184, 2000.

BAUMGARD, L.H.; MATITASHVILI, E.; CORL, B.A., et al. Trans-10, cis-12 conjugated linoleic acid decreases lipogenic rates and expression of genes involved in milk lipid synthesis in dairy cows. Journal of Dairy Science, v.85, n. 9, p. $2155-2163,2002 b$.

BELL, A.W. Regulation of organic nutrient metabolism during transition from late pregnancy to early lactation. Journal of Animal Science, v.73, n.9, p.2804-2819, 1995.

BELL, A.W.; BAUMAN, D.E. Adaptations of glucose metabolism during pregnancy and lactation. Journal of Mammary Gland Biology and Neoplasia, v.2, n.3, p.265278, 1997.

BERGERON, K.; JULIEN, P.; DAVIS, T.A., et al. Long-chain n-3 fatty acids enhance neonatal insulin-regulated protein metabolism in piglets by differentially altering muscle lipid composition. Journal of Lipid Research, v.48, n.11, p.23962410, 2007.

BERNAL-SANTOS, G.; PERFIELD, J.W., II; BARBANO, D.M., et al. Production responses of dairy cows to dietary supplementation with conjugated linoleic acid (CLA) during the transition period and early lactation. Journal of Dairy Science, v.86, n.10, p.3218-3228, 2003.

CADORNIGA-VALINO, C.; GRUMMER, R.R.; ARMENTANO, L.E., et al. Effects of fatty acids and hormones on fatty acid metabolism and gluconeogenesis in bovine hepatocytes. Journal of Dairy Science, v.80, n.4, p.646-656, 1997.

CASTANEDA-GUTIERREZ, E.; DE VETH, M.J.; LOCK, A.L., et al. Effect of supplementation with calcium salts of fish oil on n-3 fatty acids in milk fat. Journal of Dairy Science, v.90, n.9, p.4149-4156, 2007.

CASTANEDA-GUTIERREZ, E.; OVERTON, T.R.; BUTLER, W.R., et al. Dietary supplements of two doses of calcium salts of conjugated linoleic acid during the transition period and early lactation. Journal of Dairy Science, v.88, n.3, p.1078-1089, 2005.

CHILLIARD, Y.; FERLAY, A.; DOREAU, M. Effect of different types of forages, animal fat or marine oils in cow's diet on milk fat secretion and composition, especially conjugated linoleic acid (CLA) and polyunsaturated fatty acids. Livestock Production Science, v.70, n.1-2, p.31-48, 2001.

CHILLIARD, Y.; FERLAY, A.; FAULCONNIER, Y., et al. Adipose tissue metabolism and its role in adaptations to undernutrition in ruminants. Proceedings of the Nutrition Society, v.59, n.1, p.127-134, 2000.

CHILLIARD, Y.; GLASSER, F.; FERLAY, A., et al. Diet, rumen biohydrogenation and nutritional quality of cow and goat milk fat. European Journal of Lipid Science and Technology, v.109, n.8, p.828-855, 2007.

CHOUINARD, P.Y.; CORNEAU, L.; BARBANO, D.M., et al. Conjugated linoleic acids alter milk fatty acid composition and inhibit milk fat secretion in dairy cows. Journal of Nutrition, v.129, n.8, p.1579-1584, 1999a.

CHOUINARD, P.Y.; CORNEAU, L.; SABO, A., et al. Milk yield and composition during abomasal infusion of conjugated linoleic acids in dairy cows. Journal of Dairy Science, v.82, n.12, p.2737-2745, 1999 b.

CLARKE, S.D. Polyunsaturated fatty acid regulation of gene transcription: A mechanism to improve energy balance and insulin resistance. British Journal of Nutrition, v.83 Suppl 1, p.S59-66, 2000.

DE VETH, M.J.; CASTANEDA-GUTIERREZ, E.; DWYER, D.A., et al. Response to conjugated linoleic acid in dairy cows differing in energy and protein status. Journal of Dairy Science, v.89, n.12, p.4620-4631, 2006.

DE VETH, M.J.; GULATI, S.K.; LUCHINI, N.D., et al. Comparison of calcium salts and formaldehyde-protected conjugated linoleic acid in inducing milk fat depression. Journal of Dairy Science, v.88, n.5, p.1685-1693, 2005.

DELARUE, J.; LEFOLL, C.; CORPOREAU, C., et al. N-3 long chain polyunsaturated fatty acids: A nutritional tool to prevent insulin resistance associated to type 2 diabetes and obesity? Reproduction Nutrition Development, v.44, n.3, p.289-299, 2004.

DOEPEL, L.; LAPIERRE, H.; KENNELLY, J.J. Peripartum performance and metabolism of dairy cows in response to prepartum energy and protein intake. Journal of Dairy Science, v.85, n.9, p.2315-2334, 2002. 
DRACKLEY, J.K. Biology of dairy cows during the transition period: The final frontier? Journal of Dairy Science, v.82, p.2259-2273, 1999.

EDWARDS, J.L.; TOZER, P.R. Using activity and milk yield as predictors of fresh cow disorders. Journal of Dairy Science, v.87, n.2, p.524-531, 2004.

EMERY, R.S.; LIESMAN, J.S.; HERDT, T.H. Metabolism of long chain fatty acids by ruminant liver. Journal of Nutrition, v.122, n.3 Suppl, p.832-837, 1992.

GAYNOR, P.J.; ERDMAN, R.A.; TETER, B.B., et al. Milk fat yield and composition during abomasal infusion of cis or trans octadecenoates in Holstein cows. Journal of Dairy Science, v.77, n.1, p.157-165, 1994.

GINGRAS, A.-A.; WHITE, P.J.; CHOUINARD, P.Y., et al. Long-chain omega-3 fatty acids regulate bovine wholebody protein metabolism by promoting muscle insulin signalling to the akt-mtor-s6k1 pathway and insulin sensitivity. Journal of Physiology, v.579, n.1, p.269-284, 2007.

GODDEN, S.M.; STEWART, S.C.; FETROW, J.F., et al. 2003. The relationship between herd rbst-supplementation and other factors and risk for removal for cows in Minnesota Holstein dairy herds. Pages. 55-64 in Four-State Nutrtrition conference. MidWest Plan Service Publication MWPS4SD16., LaCrosse, WI.

GOFF, J.P.; HORST, R.L. Physiological changes at parturition and their relationship to metabolic disorders. Journal of Dairy Science, v.80, n.7, p.1260-1268, 1997.

GRIINARI, J.M.; CORL, B.A.; LACY, S.H., et al. Conjugated linoleic acid is synthesized endogenously in lactating dairy cows by \{delta\}9-desaturase. Journal of Nutrition, v.130, n.9, p.2285-2291, 2000.

GRIINARI, J.M.; DWYER, D.A.; MCGUIRE, M.A., et al. Trans-octadecenoic acids and milk fat depression in lactating dairy cows. Journal of Dairy Science, v.81, n.5, p.1251-1261, 1998.

GRUMMER, R.R. Etiology of lipid-related metabolic disorders in periparturient dairy cows. Journal of Dairy Science, v.76, n.12, p.3882-3896, 1993.

GRUMMER, R.R. Impact of changes in organic nutrient metabolism on feeding the transition dairy cow. Journal of Animal Science, v.73, n.9, p.2820-2833, 1995.

HARVATINE, K.J.; DWYER, D.A.; BAUMAN, D.E. Expression of lipogenic genes in adipose tissue increases during milk fat depression induced by treatment with trans10, cis-12 conjugated linoleic acid (CLA). Journal of Dairy Science, v.90 (Suppl 1), p.206 (Abstr.), 2007.

HAYIRLI, A.; GRUMMER, R.R.; NORDHEIM, E.V., et al. Models for predicting dry matter intake of holsteins during the prefresh transition period. Journal of Dairy Science, v.86, n.5, p.1771-1779, 2003.

JENKINS, T.C.; BRIDGES, W.C. Protection of fatty acids against ruminal biohydrogenation in cattle. European Journal of Lipid Science and Technology, v.109, n.8, p.778-789, 2007.

JENKINS, T.C.; WALLACE, R.J.; MOATE, P.J., et al. Boardinvited review: Recent advances in biohydrogenation of unsaturated fatty acids within the rumen microbial ecosystem. Journal of Animal Science, v.86, n.2, p.397412, 2008.

KADEGOWDA, A.K.G.; PIPEROVA, L.S.; ERDMAN, R.A. Principal component and multivariate analysis of milk long-chain fatty acid composition during diet-induced milk fat depression. Journal of Dairy Science, v.91, n.2, p.749759, 2008.

LOCK, A.L.; TYBURCZY, C.; DWYER, D.A., et al. Trans-10 octadecenoic acid does not reduce milk fat synthesis in dairy cows. Journal of Nutrition, v.137, n.1, p.71-76, 2007.

LOOR, J.J.; HERBEIN, J.H. Exogenous conjugated linoleic acid isomers reduce bovine milk fat concentration and yield by inhibiting de novo fatty acid synthesis. Journal of Nutrition, v.128, n.12, p.2411-2419, 1998.

MASHEK, D.G.; BERTICS, S.J.; GRUMMER, R.R. Metabolic fate of long-chain unsaturated fatty acids and their effects on palmitic acid metabolism and gluconeogenesis in bovine hepatocytes. Journal of Dairy Science, v.85, n.9, p.22832289,2002

MASHEK, D.G.; BERTICS, S.J.; GRUMMER, R.R. Effects of intravenous triacylglycerol emulsions on hepatic metabolism and blood metabolites in fasted dairy cows. Journal of Dairy Science, v.88, n.1, p.100-109, 2005.

MASHEK, D.G.; GRUMMER, R.R. Effects of long chain fatty acids on lipid and glucose metabolism in monolayer cultures of bovine hepatocytes. Journal of Dairy Science, v.86, n.7, p.2390-2396, 2003.

MATTOS, R.; GUZELOGLU, A.; BADINGA, L., et al. Polyunsaturated fatty acids and bovine interferon-tau modify phorbol ester-induced secretion of prostaglandin F2 alpha and expression of prostaglandin endoperoxide synthase-2 and phospholipase-A2 in bovine endometrial cells. Biology of Reproduction, v.69, n.3, p.780-787, 2003.

MATTOS, R.; STAPLES, C.R.; ARTECHE, A., et al. The effects of feeding fish oil on uterine secretion of PGF2 \{alpha\}, milk composition, and metabolic status of periparturient Holstein cows. Journal of Dairy Science, v.87, n.4, p.921-932, 2004.

MOORE, C.E.; HAFLIGER, H.C., III; MENDIVIL, O.B., et al. Increasing amounts of conjugated linoleic acid (CLA) progressively reduces milk fat synthesis immediately postpartum. Journal of Dairy Science, v.87, n.6, p.18861895,2004

MOUSSAVI, A.R.H.; GILBERT, R.O.; OVERTON, T.R., et al. Effects of feeding fish meal and n-3 fatty acids on milk yield and metabolic responses in early lactating dairy cows. Journal of Dairy Science, v.90, n.1, p.136-144, 2007a.

MOUSSAVI, A.R.H.; GILBERT, R.O.; OVERTON, T.R., et al. Effects of feeding fish meal and n-3 fatty acids on ovarian and uterine responses in early lactating dairy cows. Journal of Dairy Science, v.90, n.1, p.145-154, 2007b.

MUSTAD, V.A.; DEMICHELE, S.; HUANG, Y.-S., et al. Differential effects of n-3 polyunsaturated fatty acids on metabolic control and vascular reactivity in the type 2 diabetic ob/ob mouse. Metabolism: Clinical and Experimental, v.55, n.10, p.1365-1374, 2006.

ODENS, L.J.; BURGOS, R.; INNOCENTI, M., et al. Effects of varying doses of supplemental conjugated linoleic acid on production and energetic variables during the transition period. Journal of Dairy Science, v.90, n.1, p.293-305, 2007.

PARIZA, M.W. Perspective on the safety and effectiveness of conjugated linoleic acid. American Journal of Clinical Nutrition, v.79, n.6, p.1132S-1136, 2004.

PARIZA, M.W.; PARK, Y.; COOK, M.E. The biologically active isomers of conjugated linoleic acid. Progress in Lipid Research, v.40, n.4, p.283-298, 2001.

PENNINGTON, J.A.; DAVIS, C.L. Effects of intraruminal and intra-abomasal additions of cod-liver oil on milk fat 
production in the cow. Journal of Dairy Science, v.58, n.1, p.49-55, 1975.

PERFIELD, J.W., II; BERNAL-SANTOS, G.; OVERTON, T.R., et al. Effects of dietary supplementation of rumen-protected conjugated linoleic acid in dairy cows during established lactation. Journal of Dairy Science, v.85, n.10, p.26092617,2002

PERFIELD, J.W., II; LOCK, A.L.; GRIINARI, J.M., et al. Trans9, cis-11 conjugated linoleic acid reduces milk fat synthesis in lactating dairy cows. Journal of Dairy Science, v.90, n.5, p.2211-2218, 2007.

PERFIELD, J.W., II; LOCK, A.L.; PFEIFFER, A.M., et al. Effects of amide-protected and lipid-encapsulated conjugated linoleic acid (CLA) supplements on milk fat synthesis. Journal of Dairy Science, v.87, n.9, p.3010-3016, 2004.

PETERSON, D.G.; MATITASHVILI, E.A.; BAUMAN, D.E. Diet-induced milk fat depression in dairy cows results in increased trans-10, cis-12 CLA in milk fat and coordinate suppression of mrna abundance for mammary enzymes involved in milk fat synthesis. Journal of Nutrition, v.133, n.10, p.3098-3102, 2003.

PETIT, H.V. Digestion, milk production, milk composition, and blood composition of dairy cows fed whole flaxseed. Journal of Dairy Science, v.85, n.6, p.1482-1490, 2002.

PETIT, H.V.; PALIN, M.F.; DOEPEL, L. Hepatic lipid metabolism in transition dairy cows fed flaxseed. Journal of Dairy Science, v.90, n.10, p.4780-4792, 2007.

PETTERSON, J.A.; DUNSHEA, F.R.; EHRHARDT, R.A., et al. Pregnancy and undernutrition alter glucose metabolic responses to insulin in sheep. Journal of Nutrition, v.123, n.7, p.1286-1295, 1993.

PETTERSON, J.A.; DUNSHEA, F.R.; EHRHARDT, R.A., et al. Pregnancy but not moderate undernutrition attenuates insulin suppression of fat mobilization in sheep. Journal of Nutrition, v.124, p.2431-2437, 1994.

PIRES, J.A.A.; GRUMMER, R.R.; MASHEK, D.G., et al. Modulation of bovine hepatic ApoB100, ApoE and MTP gene expression by fatty acids. Journal of Dairy Science, v.89 (Suppl. 1), p.349(Abstr.), 2006.

PIRES, J.A.A.; GRUMMER, R.R.; MASHEK, D.G., et al. Modulation of bovine hepatic lipid metabolism by fatty acids. Journal of Dairy Science, v.87 (Suppl. 1), p.336(Abstr.), 2004.

PIRES, J.A.A.; PESCARA, J.B.; BRICKNER, A.E., et al. Effects of abomasal infusion of linseed oil on responses to glucose and insulin in Holstein cows. Journal of Dairy Science, v.91, n.4, p.1378-1390, 2008.

PIRES, J.A.A.; PESCARA, J.B.; GRUMMER, R.R. Reduction of plasma NEFA concentration by nicotinic acid enhances the response to insulin in feed-restricted Holstein cows. Journal of Dairy Science, v.90, n.10, p.4635-4642, 2007a.

PIRES, J.A.A.; SOUZA, A.H.; GRUMMER, R.R. Induction of hyperlipidemia by intravenous infusion of tallow emulsion causes insulin resistance in Holstein cows. Journal of Dairy Science, v.90, n.6, p.2735-2744, 2007b.
RABELO, E.; REZENDE, R.L.; BERTICS, S.J., et al. Effects of transition diets varying in dietary energy density on lactation performance and ruminal parameters of dairy cows. Journal of Dairy Science, v.86, n.3, p.916-925, 2003.

REYNOLDS, C.K.; AIKMAN, P.C.; LUPOLI, B., et al. Splanchnic metabolism of dairy cows during the transition from late gestation through early lactation. Journal of Dairy Science, v.86, n.4, p.1201-1217, 2003.

ROBERTS, C.J.; REID, I.M.; ROWLANDS, G.J., et al. A fat mobilisation syndrome in dairy cows in early lactation. Veterinary Record, v.108, n.1, p.7-9, 1981.

ROMO, G.A.; CASPER, D.P.; ERDMAN, R.A., et al. Abomasal infusion of cis or trans fatty acid isomers and energy metabolism of lactating dairy cows. Journal of Dairy Science, v.79, n.11, p.2005-2015, 1996.

SAEBO, A.; SAEBO, P.C.; GRIINARI, J.M., et al. Effect of abomasal infusions of geometric isomers of 10,12 conjugated linoleic acid on milk fat synthesis in dairy cows. Lipids, v.40, n.8, p.823-832, 2005.

SAMPATH, H.; NTAMBI, J.M. Polyunsaturated fatty acid regulation of gene expression. Nutrition Reviews, v.62, n.9, p.333-339, 2004.

SHINGFIELD, K.J.; GRIINARI, J.M. Role of biohydrogenation intermediates in milk fat depression. European Journal of Lipid Science and Technology, v.109, n.8, p.799-816, 2007.

STAPLES, C.R.; BURKE, J.M.; THATCHER, W.W. Influence of supplemental fats on reproductive tissues and performance of lactating cows. Journal of Dairy Science, v.81, n.3, p.856-871, 1998.

STORLIEN, L.H.; HIGGINS, J.A.; THOMAS, T.C., et al. Diet composition and insulin action in animal models. British Journal of Nutrition, v.83 Suppl 1, p.S85-90, 2000.

STORLIEN, L.H.; JENKINS, A.B.; CHISHOLM, D.J., et al. Influence of dietary-fat composition on development of insulin resistance in rats - relationship to muscle triglyceride and omega-3-fatty-acids in muscle phospholipid. Diabetes, v.40, n.2, p.280-289, 1991.

STORLIEN, L.H.; KRAEGEN, E.W.; CHISHOLM, D.J., et al. Fish oil prevents insulin resistance induced by high-fat feeding in rats. Science, v.237, n.4817, p.885-888, 1987.

STRANG, B.D.; BERTICS, S.J.; GRUMMER, R.R., et al. Effect of long-chain fatty acids on triglyceride accumulation, gluconeogenesis, and ureagenesis in bovine hepatocytes. Journal of Dairy Science, v.81, n.3, p.728-739, 1998.

TAOUIS, M.; DAGOU, C.; STER, C., et al. N-3 polyunsaturated fatty acids prevent the defect of insulin receptor signaling in muscle. American journal of physiology. Endocrinology and metabolism, v.282, n.3, p.E664-671, 2002.

VAZQUEZ-AÑON, M.; BERTICS, S.; LUCK, M., et al. Peripartum liver triglyceride and plasma metabolites in dairy cows. Journal of Dairy Science, v.77, n.6, p.15211528,1994

VEENHUIZEN, J.J.; DRACKLEY, J.K.; RICHARD, M.J., et al. Metabolic changes in blood and liver during development and early treatment of experimental fatty liver and ketosis in cows. Journal of Dairy Science, v.74, n.12, p.4238-4253, 1991.

VESSBY, B. Dietary fat and insulin action in humans. British Journal of Nutrition, v.83(Suppl. 1), p.S91-S96, 2000. 